\title{
Note
}

\section{Maternal age, development time, position effect variegation in Drosophila melanogaster}

\author{
A. MILLS and I. HARTMANN-GOL.DSTEIN * \\ I.N.R.A., Station de Recherches avicoles \\ Centre de Recherches de Tours, Nouzilly, F 37380 Monnaie \\ * Department of Genetics. University of Sheffield \\ Western Bank, Sheffield S10 2TN, Great Britain
}

\begin{abstract}
Summary
In Drosophila expression of position-effect variegation is enhanced by culturing flies at low temperatures. It is demonstrated that this effect may not be solely temperature dependent. Maternal age influences offspring development times. Futhermore, at a given temperature, the longer a fly takes to develop, the more likely is it to exhibit position-effect variegation.
\end{abstract}

Key words : Maternal age, development time, Drosophila, position-effect.

\section{Résumé}

Age maternel, durée de développement et effet de position (type « variegation ») chez Drosophila melanogaster

Chez la Drosophile, l'expression de la diversité de «l'effet position» est favorisée lorsque les mouches se développent sous des températures basses. Il a été démontré que cet effet n'est pas uniquement dépendant de la température. L'âge maternel influence la durée de développement des descendants. De plus, pour une température donnée, il semble que plus la durée de développement est longue, plus l'expression de "l'effet position 》 est diversifiée.

Mots clés : Age maternel, durée de développement, Drosophile, effet position.

\section{Introduction}

In Drosophila $s p$. the transposition of genes, which accompanies chromosome translocations, sometimes results in changes in gene action which are expressed as mutant phenotypes (SPOFFORD, 1976). Such phenomena are known as position-effects 
(Sturtevant, 1925). Position-effects are of two types (Spofford, 1976). In one type the change in gene action is somatically stable and is expressed in all cells. In the other type the change in gene action is subject to wide and frequent statistical fluctuation in homogenous cells. In certain tissues, for example the ommatidia of the compound eye (HARTMANN-GoldsteIN, 1967), this results in somatic mosaicisms which are generally known as « eversporting displacements " (MUELler, 1930), or "variegations » (Schultz, 1936).

Position-effect variegation may thus be defined as the mosaic expression of a gene (or genes) lying near the "break-point » in a chromosome re-arrangement (SPOFFORD, 1976). However, not all translocations induce variegation; and the phenomenon is generally restricted to those transpositions which bring genes normally lying in euchromatic chromosomal segments into the vicinity of heterochromatin (LEWIS, 1950 ; SPOFFORD, 1976).

Variegated phenotypes are a reflection of localised gene deactivation, i.e. of a gene being active in some cells but not in others. In the majority of cases the effect appears to be attributable to the heterochromatization of transposed euchromatin within affected cells (Hartmann-Goldstein, 1967 ; Spofford, 1976). However the exact cytochemical and molecular mechanisms of variegation are not well understood.

One of the characteristics of position-effect variegation is the sensitivity of the variegated phenotype to factors extrinsic to the actual chromosome translocation. Temperature at critical stages during development, the amount of heterochromatin in the genome, the parental source of the translocated chromosome segment, and other gene loci may all act as modifiers of the expression of variegation associated with a given translocation (SPOFFORD, 1976).

In strain $\mathrm{T}(1: 4) w^{\mathrm{m}} 258-21 /$ In (1) $\triangle 49 w^{\mathrm{lz}}$ of Drosophila melanogaster (LiNDSLEY \& GRELL, 1968), hereafter refered to as $w^{\mathrm{m} 258-21}$, position-effect on band 3C7 of a translocated X chromosome results in variegation in expression of the Notch locus (HARTMANN-Goldstein, 1967); a wing abnormality which involves variable nicking or scalloping of the wing margins, thickening of the wing veins, and bristle abnormalities (Welshons, 1965, see also figure 4).

Expression of variegation of the Notch phenotype in strain $w^{m 258-21}$ can be enhanced by culturing the strain at low temperatures. This effect is apparently exerted during the embryonic and larval stages of development (HARTMANN-GOLDSTEIN, 1967).

In view of this, since it is common knowledge that in Drosophila sp. low ambient temperatures prolong generation times, and thus the duration of developmental stages, the question arises as to whether or not the variegation seen in flies raised at low temperatures is a direct effect of temperature, or is a consequence of extended development time which for some reason 'permits' more variegation. In order to try and answer this question we studied the incidence of Notch variegation in flies whose development times differed because of a factor other than temperature.

Since parental age is known to influence larval development time in D. melanogaster (SANG, 1956; Delcour, 1969), we took eggs from flies of different ages and investigated the influences of parental age and development time on the incidence of Notch variegation. 


\section{Material and methods}

Pure line flies from the strain $w^{m 258-21}$ of $D$. melanogaster were used throughout the study. Variegation of the Notch phenotype in this strain occurs as a consequence of position-effect on salivary band $3 \mathrm{C} 7$ of the X-chromosome, arising through the translocation of the distal portion of one X-chromosome to a position proximal to the chromocentre. The translocation is both hemi and homozygous lethal. The nontranslocated X-homologue carries the white $(w)$ allele, and an inversion that is homozygous sterilising. Each generation of the strain thus contains white eyed males hemizygous for the inversion, white eyed females homozygous for the inversion, hereafter refered to as $\mathrm{X}^{\mathrm{i}} \mathrm{X}^{\mathrm{i}}$ females, and red-eyed females heterozygous for the inversion and the translocation, hereafter refered to as $X^{t} X^{i}$ females (MILLS, 1979). The development times of males, $\mathrm{X}^{i} \mathrm{X}^{\mathrm{i}}$ females, and $\mathrm{X}^{t} \mathrm{X}^{\mathrm{i}}$ females were considered separately ; and as only $\mathrm{X}^{\mathbf{t}} \mathrm{X}^{\mathrm{i}}$ females exhibit the Notch phenotype study of the incidence of variegation was by necessity restricted to flies of this type.

The development rate of $D$. melanogaster is influenced by various factors such as ambient temperature, larval diet, and larval population density (SANG, 1956 ; DeLcouR, 1969). In designing this experiment every care was taken to ensure that culture conditions were constant for all larval populations.

A total of 30 replicate populations of flies $\left(25 \delta^{\top} \sigma^{\pi}\right.$ and 25 우 in each) were used. Each group of flies was maintained at $19^{\circ} \mathrm{C}$. Eggs were taken from flies whose mean ages $( \pm 0.5 \mathrm{~d}$.) were $3.5,4.5,6.5,9.5,12.5$ and $15.5 \mathrm{~d}$. respectively. Since the developmental stage of freshly deposited $D$. melanogaster eggs may be anywhere between the moment after fertilization to just before emergence of the larvae (HUETTNER, 1923) which in strain $w^{\mathrm{m} 258-21}$, at $19^{\circ} \mathrm{C}$, represents a period of $55 \mathrm{hr}$ (HARTMANNGoldsteIn, 1967), eggs were collected only from females which were likely to have already laid during the two hours prior to collection of eggs. This was achieved in the following manner. Each of the 30 replicate populations of flies ( $\sigma^{\pi} \delta^{\pi}$ and $q q$ ) was transfered to an empty wide necked bottle. Each of these bottles was then capped with an agar filled watch glass. The bottles were then inverted and left for $1 \mathrm{hr}$. At the end of this period each bottle was re-capped with a fresh agar filled watch glass and left for a further $2 \mathrm{hr}$. Eggs laid on the first agar cap were discarded. Eggs laid on the second agar cap were retained for experimental purposes, but only if a large number $(>20)$ of eggs had been laid in the first hour. This technique for the collection of fresh $D$. melanogaster eggs is essentially similar to that described by SONNENBLICK (1950). The uterus of the fruit-fly contains only one egg at a time (NonIDEZ, 1920), thus when a female lays more than one egg in a relatively short period of time, the second and subsequent eggs will be at similar stages of development i.e. shortly after fertilization. Thus by taking eggs only from females which were likely to have laid shortly beforehand we were able to ensure that most, if not all, of the eggs taken were at a similar stage of development. After collection batches of 55 eggs were 'seeded' in $2.5 \mathrm{~cm}$ diameter vials containing $5 \mathrm{ml}$ of glucose-yeast culture medium. The vials were then placed in a culture room maintained at $19^{\circ} \mathrm{C}$, and the larvae left to develop. Once imagines commenced to eclose vials were cleared daily, the development times of the flies noted, and $X^{t} X^{i}$ females scored for the presence or absence of the Notch phenotype. A fuller description of the experimental procedures used is given by MiLls (1979). 


\section{Results}

Figure 1 shows the influence of maternal age on development times. Although there were significant differences between the development times of males, $\mathrm{X}^{\mathbf{i}} \mathrm{X}^{\mathbf{i}}$, and $\mathrm{X}^{\mathrm{t}} \mathrm{X}^{\mathrm{i}}$ females - in general males exhibited the longest development times, and $\mathrm{X}^{\mathrm{t}} \mathrm{X}^{\mathrm{i}}$ females the shortest - the influence of maternal age was the same in all 3 groups.

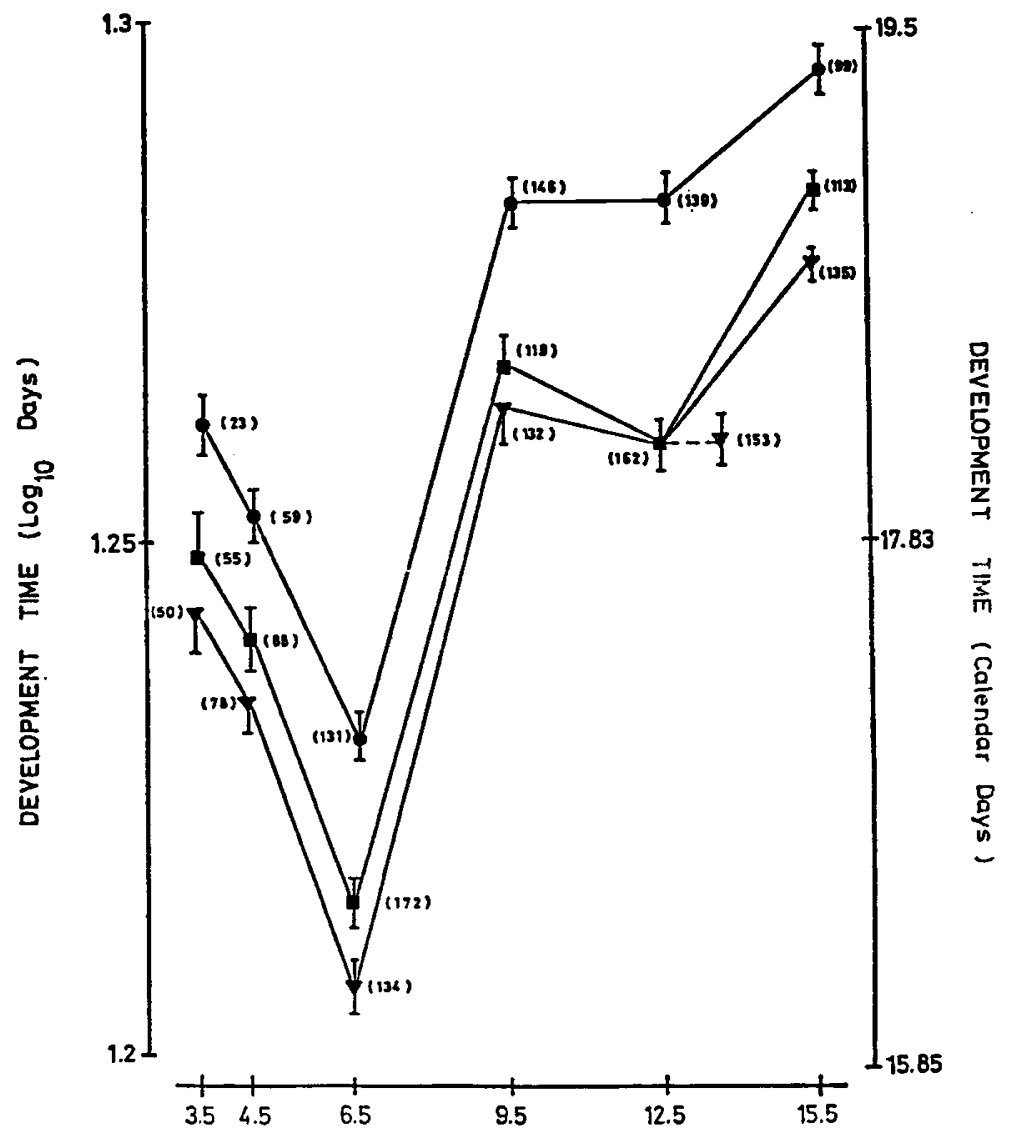

FIG. 1

The influence of maternal age on progeny development times in strain $T|1: 4| \mathrm{w}^{\mathrm{m}} 258-21 / \ln |1|$

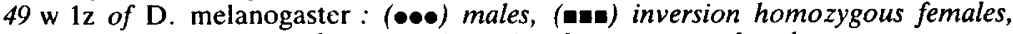
(v) translocation: inversion heterozygous females.

Values are means ( \pm S.E.M.). Numbers in parentheses are the numbers offspring produced by each maternal age group.

L'influence de l'âge maternel sur la durée du développement des descendants dans la lignée $T|1: 4| \mathrm{w}^{\mathrm{m} 258-21} \int \ln |1| 49 \mathrm{w} 1 \mathrm{z}$ de $\mathrm{D}$. melanogaster.

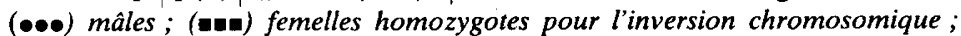

(vv) femelles hétérozygotes pour l'inversion translocation chromosomique. Les points représentent la moyenne $( \pm$ S.E.M.). Les nombres entre parenthèses indiquent l'effectif d'animaux par point. 


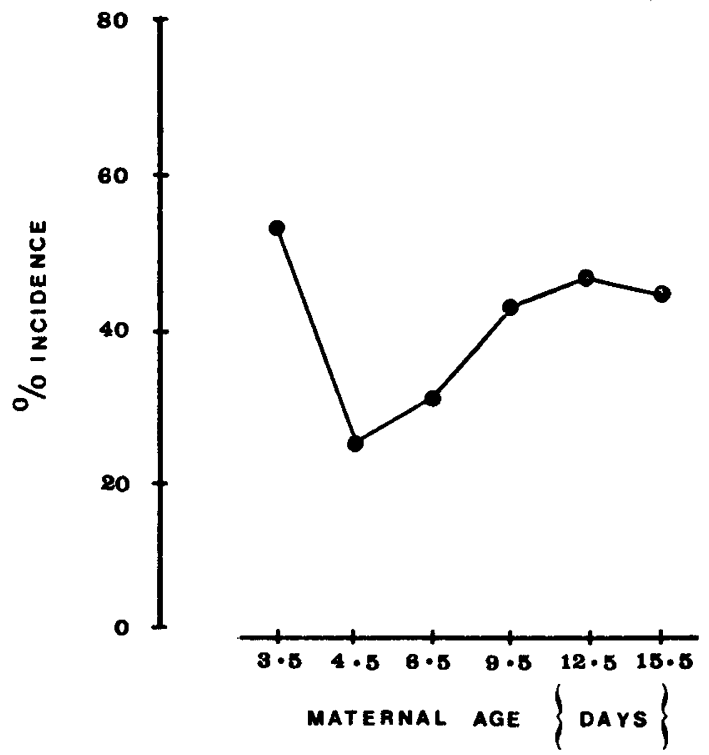

FIG. 2

The percentage incidences of the Notch phenotype in the progenies of flies of different ages.

Influence de l'âge de la mère sur le pourcentage de descendants présentant le phénotype Notch.

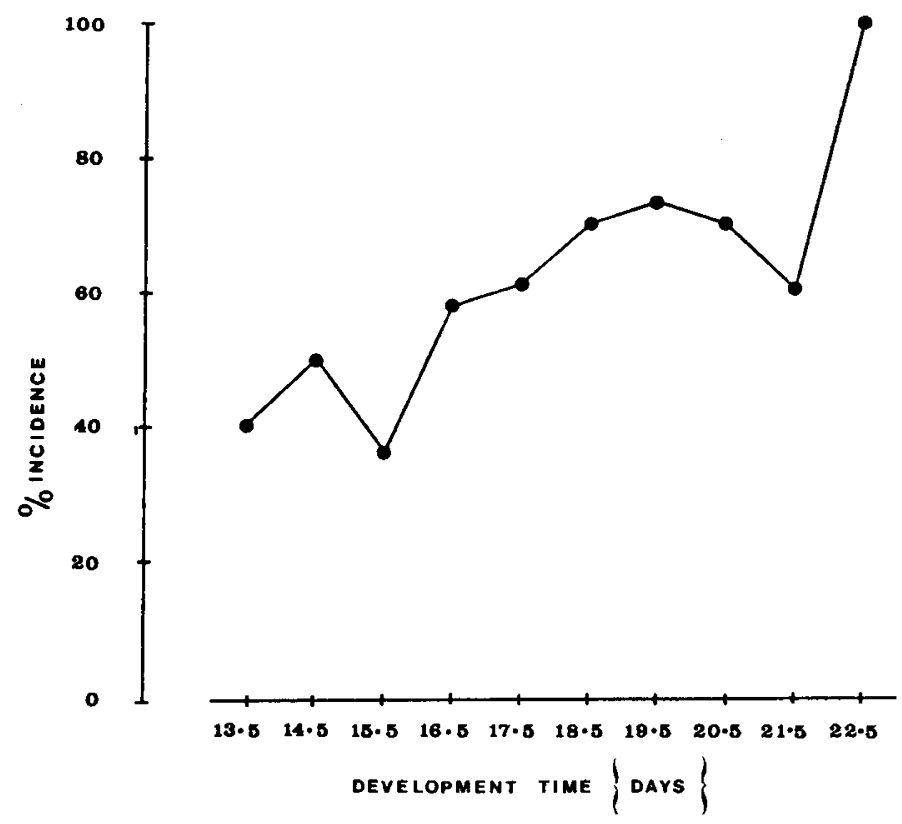

FiG. 3

The percentage incidences of the Notch phenotype in flies of different development times. Influence de la durée de développement sur le pourcentage de descendants présentant le phénotype Notch. 


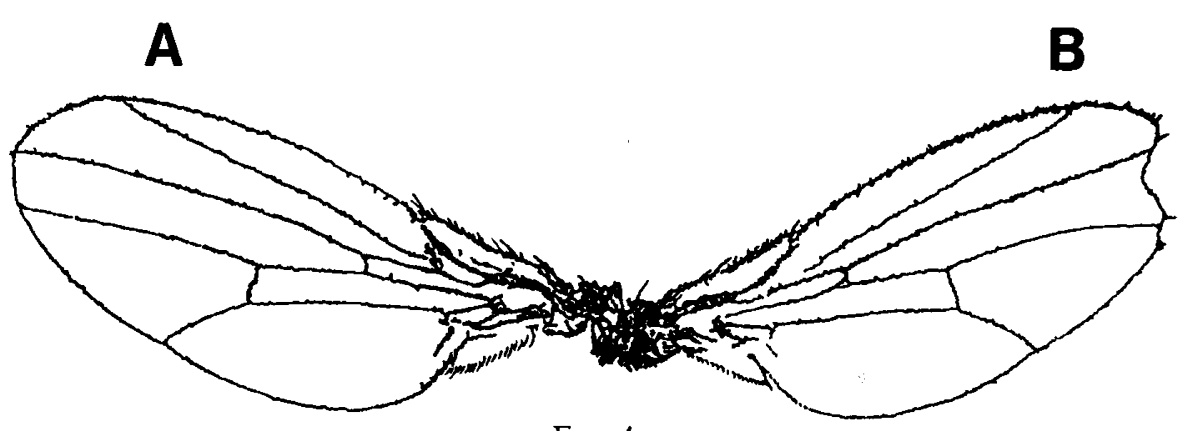

FIG. 4

Scalloping of the wing-margin attributable to position-effect on the Notch locus. Entaille de l'aile $B$ imputable à l'effet position sur le locus Notch.

A : Normal wing - Aile normale.

B : Scalloped wing - Aile entaillée.

The length of the developmental period decreased with maternal age up to 6.5 days, increased sharply between 6.5 and 9.5 days, and thereafter showed a general though fluctuating tendency to increase.

The incidence of the Notch phenotype (i.e. the proportion of flies exhibiting the phenotype) decreased with parental age up to 4.5 days. Thereafter the incidence of Notch was positively correlated with parental age $(\mathrm{r}=0.9126, \mathrm{n}=616,0.05>\mathrm{P}>$ 0.02 , fig. 2). The incidence of Notch was also positively correlated with the development time of the flies $(r=0.7666, n=659, P<0.001$, fig. 3 ).

\section{Discussion and conclusions}

These present results do not explain why maternal age influences progeny development times. Nor do they shed much light on the cytochemical and molecular mechanisms of position-effect variegation. However, what these results do indicate is that, at least in strain $w^{\mathrm{m} 258-21}$, low ambient temperature enhancement of position-effect variegation is not necessarily a direct effect of temperature, but is in part a function of extended development time. This finding is consistent with HartmanNGoldstein's (1967) suggestion that there are 'sensitive' periods during development, which if extended, and/or if during which animals are subjected to environmental shocks (e.g. temperature), expression of position-effect variegation may be influenced. Quite how this effect operates is unclear, but it has been demonstrated that ageing brings about physiological changes in the Drosophila female (RoBERTSON \& SANG, 1944) ; and it is tempting to speculate that the influence of maternal age on development time and the relationship between development time and expression of position effect variegation are in some way related. 


\section{References}

Delcour J., 1969. Influence de l'âge parental sur la dimension des œufs, la durée de développement, et la taille thoracique des descendants, chez Drosophila melanogaster. J. Insect Physiol., 15, 1999-2011.

HARTMANN-GoldSTEIN I.J., 1967. On the relationship between heterochromatization and variegation in Drosophila with special reference to temperature sensitive-periods. Genet. Res. (Camb.), 10, 143-159.

Huettner A.F., 1923. The origin of germ cells in Drosophila melanogaster. J. Morphol., 37, 385-423.

Lewis E.B., 1950. The phenomenon of position effect. In : Demerec M. (ed.), Advances in genetics, 3, 73-115, Academic Press.

Lindsley D.L., Grell E.H., 1968. Genetic variations of Drosophila melanogaster. Carnegie Inst. Publ., 627, Washington.

Mills A.D., 1979. Parental age, development time, and position effect variegation in Drosophila melanogaster. B. Sc. Thesis. University of Sheffield.

Muller H.J., 1930. Types of visible variations induced by x-rays in Drosophila. J. Genet., 22, 299-334.

Nonidez J.F., 1920. The internal phenomena of reproduction in Drosophila. Biol. Bull., 39, 207-230.

Robertson F.W., SANG J.H., 1944. Effect of nutrition on fecundity and egg hatching : Drosophila. Proc. R. Soc. B. (Edin.), 132, 258-290.

SANG J.H., 1956. The quantitative nutritional requirements of Drosophila melanogaster. J. Exp. Biol., 35, 832-842.

Schultz J., 1936. Variegation in Drosophila and inert chromosome regions. Proc. Natl. Acad. Sci. U.S.A., 22, 27-33.

SONNENBLICK B.P., 1950. The early embryology of Drosophila melanogaster. In : Demerec M. (ed.), Biology of Drosophila, 62-167, John Wiley \& Sons, New York.

SPOFFord J.B., 1976. Position-effect variegation in Drosophila. In : AshbuRner M., NovitSKi E. (eds.), The Genetics and Biology of Drosophila, 955-1009, Academic Press.

Sturtevant A.H., 1925. The effects of unequal crossing over at the Bar locus in Drosophila. Genetics, 10, 117-147.

Welshons W.J., 1965. Analysis of a gene in Drosophila. Science, 150, 1122-1129. 